DOI: $10.17951 / \operatorname{lrp} .2020 .39 .2 .63-72$

\author{
Grzegorz GodAwA \\ Uniwersytet Papieski Jana Pawła II w Krakowie \\ ORCID - 0000-0002-2283-3965
}

\title{
WARTOŚCI W RODZINIE ZACZERPNIĘTE OD DZIECI
}

\begin{abstract}
Streszczenie: Przekaz wartości w wychowaniu w rodzinie jest zwykle ukierunkowany na dziecko. Możliwe jest także oddziaływanie w odwrotnym kierunku. Wynika ono z istotnego znaczenia interakcji w rodzinnej edukacji aksjologicznej. $\mathrm{Na}$ ich podstawie w wychowaniu dokonuje się obustronny przekaz komunikatów, co umożliwia oddziaływanie dziecka na wartości rodziców. Oddziaływanie dzieci na hierarchię wartości rodziców dokonuje się poprzez bierny i aktywny wpływ dziecka, różnicowanie wartości, wzajemne wzmacnianie i wpływ przeciwstawny. Opisanie tych obszarów pozwala dostrzec znaczenie stosunku wychowawczego w rodzinie, a także możliwości jego modyfikacji. Jednocześnie zwraca uwagę na właściwe ujęcie roli dziecka w aksjologicznych przemianach $\mathrm{w}$ rodzinie.
\end{abstract}

Słowa kluczowe: dziecko, rodzice, przekaz wartości

\section{WPROWADZENIE}

Każda rodzina tworzy własny, niepowtarzalny system wychowawczy, który jest oparty na uznawanej hierarchii wartości oraz na wynikających z niej normach społecznych i etycznych. System ten przejawia się w postawach rodzicielskich, więziach uczuciowych między członkami rodziny oraz w relacjach społeczno-emocjonalnych między rodzicami i dziećmi (Cudak 2011, s. 5).

Kontekst aksjologiczny nabiera szczególnego znaczenia w życiu rodzinnym. W sensie ontologicznym każdy członek rodziny jest w pełni wartościową osobą, a uznawane przez niego wartości stanowią o tym, jak funkcjonuje rodzina. W wymiarze wychowawczym wartości są wyzwaniem inspirującym do wzrostu osobowościowego członków rodziny i wzmacniającym więzi pomiędzy nimi. By tak się stało, niezbędny jest ich przekaz. Może on odbywać się poprzez dialog osobowy, który wymaga „wspólnej płaszczyzny porozumienia, a potem uczenia się słucha- 
nia i rozmowy. Jego istotę stanowi dążenie podmiotów, czyli rodziców i dzieci do wzajemnego zrozumienia, zbliżenia się do siebie i współdziałania. Dialog rodzica z dzieckiem lub małżonkiem, umożliwiający poznanie go, zrozumienie i dążenie do współpracy, staje się obecnie nieodzowny” (Buczek 2015, s. 17). Dialog zakłada wymienność przekazu, a w odniesieniu do transmisji wartości w rodzinie wymaga on otwartości na wartości prezentowane zarówno przez rodziców, jak i dzieci.

Ostatni z wymienionych wymiarów dialogu aksjologicznego stanowi interesujące wyzwanie poznawcze. Mimo że skupienie uwagi na dziecku we współczesnej pedagogice nieustannie wzrasta, spojrzenie na wychowanka jak na źródło i przekaziciela wartości wydaje się niewystarczająco zbadaną rzeczywistością. Tymczasem stanowi ona ważny obszar funkcjonowania i rozwoju rodziny. Dlatego zasadne jest ukazanie rodziny jako środowiska interakcji, dzięki którym wartości są odkrywane i przekazywane nie tylko przez rodziców, ale także przez dzieci.

\section{WARTOŚCI I ICH PRZEKAZ W RODZINIE}

Wincenty Okoń ujmuje wartość na dwa sposoby. Pierwszy z nich jest obiektywistyczny, a wartość stanowi „właściwość przedmiotów, niezależnie od tego, jak je oceniają ludzie". Drugi wymiar jest subiektywistyczny, a wartość jest traktowana jako „właściwość nadawana przedmiotom przez człowieka w zależności od jego potrzeb, uczuć i woli” (Okoń 2004, s. 449). Rozróżnienie to pozwala dostrzec, że w podejściu do wartości ważna jest ich wewnętrzna struktura, a także ich subiektywne postrzeganie.

Wartość jest podstawową kategorią aksjologii. Według Jana Galarowicza oznacza ona wszystko, co jest cenne, ważne, doniosłe, a w szczególnym znaczeniu ważne samo w sobie (Galarowicz 2011, s. 269). Wartości określają relację człowiek - człowiek, człowiek - grupa społeczna, człowiek - środowisko społeczne (Chałas 2006, s. 32). Stanowią one również podstawę relacji między jednostkami lub grupami, integrując je (Ryczan 1997, s. 556): „Wartości obejmują i porządkują wszystkie wymiary życia ludzkiego. Dotyczą sfery fizycznej, psychicznej, duchowej i społecznej. Stanowią kryteria, które umożliwiają człowiekowi integralny rozwój oraz realizację jego aspiracji życiowych. Wartości określają nasze postawy wobec ludzi oraz rzeczy. Mają wpływ na stany emocjonalne oraz na samoocenę" (Dudzik, Nowak 2017, s. 10). Związek wychowania z rozwojem człowieka oraz jego funkcjonowaniem we wspólnocie ukierunkowuje dalsze rozważania aksjologiczne na środowisko rodzinne, w którym dokonuje się międzypokoleniowy przekaz wartości.

Założenie dotyczące znaczenia rodziny wydaje się w pełni uzasadnione: „W relacji rodzinnej sytuacja aksjologiczna ma miejsce nieprzerwanie, ponieważ 
w każdym momencie codzienności, każdy jej członek zanurzony jest w silne, z zasady, pozytywne stosunki wzajemne, ma określoną pozycję i pełni jednocześnie wiele ról” (Jezierska-Wiejak 2013, s. 294). Przekaz wartości dokonuje się w dużym stopniu poprzez uczestniczenie w życiu rodziny, w którym sytuacje niezamierzone i zamierzone posiadają znaczenie wychowawcze (Kawula 2007, s. 57). Co ciekawe, analiza procesu przekazu wartości jest zwykle jednokierunkowa - dorośli przekazują je dziecku. Tworzenie habitusu dziecka dokonuje się poprzez oddziaływanie, określane niekiedy jako przemoc symboliczna, która jest dyskretną formą manipulacji (Suchocka 2011, s. 295). To negatywne spojrzenie na proces wychowania zaprezentowane przez Pierre'a Bourdieu dotyczy sytuacji, w których rodzice chcą wpływać na postawy dzieci, nie biorąc pod uwagę ich potrzeb, przekonań i wolności. Zamykają się wtedy na przestrzeń dialogu oraz budowanie poprawnych i silnych interakcji. $Z$ kolei manipulacja rozumiana pozytywnie nie niweczy istoty wychowania i podmiotowości wychowanka, nie odwołuje się do metod i działań nieetycznych, ale ujawnia intencje i zamierzenia wychowawcze (Sowiński 2013, s. 367).

W przekazie wartości niezmiernie ważne jest znacznie interakcji. Stają się one tłem dla dokonujących się przemian i rozwoju człowieka (Kuczynski 2003, s. 7). Interakcje rodzinne należą do interakcji społecznych, czyli procesów wzajemnego oddziaływania osób, które pod ich wpływem modyfikują swoje zachowania. Oddziaływania te dokonują się poprzez procesy komunikowania się, a także przekazywania wrażeń (Gurba 2013, s. 25). Interakcja zakłada współdziałanie i możliwość obustronnego przekazu komunikatów, a przez to możliwość zmian we wszystkich podmiotach interakcji.

Wychowanie interakcyjne zakłada, że „wychowanek jest godnym partnerem swego wychowawcy, że nie jest i nie może być jedynie przedmiotem zewnętrznych oddziaływań, jest także - podmiotem własnego działania, zasługującym na wysłuchanie i dialog. Słusznie uznaje się wychowanka za równoprawnego partnera $\mathrm{w}$ procesie wychowawczym. Wprawdzie w porównaniu $\mathrm{z}$ wychowawcą jest $\mathrm{z}$ reguły partnerem mniej doświadczonym, ale nigdy nie da się go wykluczyć jako ważnego ogniwa istniejącej interakcji” (Zarzecki 2012, s. 42).

Postrzeganie wychowanka jako równoprawnego partnera procesu wychowania uzasadnia przyjęcie założenia, że może on być także źródłem oddziaływania wychowawczego. Może ono zostać ukierunkowane na osobę bardziej życiowo doświadczoną, czyniąc interakcję pasem transmisyjnym wartości, których beneficjentami są wychowawcy. 


\section{OBSZARY ODDZIAŁYWANIA DZIECI NA RODZICÓW}

Wśród nielicznych publikacji poruszających zagadnienie wpływu dzieci na rodziców, rozpatrywanym w kontekście przekazywania wartości, na szczególną uwagę zasługuje publikacja Ariel Knafo i Neta Galansky. Autorzy przedstawiają w niej procesy, które stanowią składowe wpływu dzieci na wartości uznawane przez rodziców. Do tych procesów należą: bierny wpływ dziecka, aktywny wpływ dziecka, różnicowanie wartości, wzajemne wpływy i wpływ przeciwstawny (Knafo, Galansky 2008, s. 1145). Warto pogłębić jego znaczenie i odnieść do konkretnych sytuacji wychowawczych w rodzinie.

Bierny wpływ dziecka obejmuje zmiany, jakie dokonują się w rodzicielskiej hierarchii wartości w związku z narodzinami dzieci lub w okresie, kiedy wchodzą one w nowe stadia rozwojowe. Impulsem sprzyjającym zmianom może być przeżywanie okresu oczekiwania na narodzenie się dziecka, a przez to odkrywanie wartości własnego rodzicielstwa (Kornas-Biela 2009, s. 94). Obserwacja dziecka i towarzyszenie mu w procesie rozwojowym może radykalnie wpłynąć na tożsamość rodzica oraz dokonać przewartościowania w jego sposobie postrzegania świata. Dokonuje się to przy biernej postawie dziecka, które nie jest świadome wywieranego wpływu. Szczególnym nośnikiem zachodzących zmian może być uśmiech dziecka. Często jest to uśmiech spontaniczny, który nie zawsze ma konkretny powód. Przykładem może być uśmiech społeczny, pojawiający się u dziecka około 3. miesiąca życia. Niemowlę kieruje zachowania przywiązaniowe w stronę wszystkich osób ze swojego otoczenia, zwracając głowę w ich kierunku, śledząc wzrokiem, wokalizując i uśmiechając się (Kotarba 2011, s. 89). Te zachowania powodują, że rodzice spędzają z dzieckiem więcej czasu, poddając się jego nieświadomemu oddziaływaniu. Jego zewnętrznym przejawem jest odwzajemnienie uśmiechu przez osoby dorosłe, na co dzień funkcjonujące w świecie, w którym spontaniczny i bezinteresowny uśmiech nie jest częstym zjawiskiem (Vohra, What Can Adults Learn from Children?).

Aktywny wpływ dziecka na system wartości rodziców może przybierać dwie formy. Dzieci podejmują próby bezpośredniego wpłynięcia na opinie rodziców lub dostarczają rodzicom istotnych informacji, które pośrednio modyfikują ich hierarchię wartości. Oceny postępowania rodziców dokonywane przez dzieci i stawiane przez nie pytania stają się bodźcem do przemyśleń i przewartościowań. Jest to szczególnie widoczne w obszarze nabywania nowej wiedzy lub wykorzystywania wcześniej nabytych informacji. Dzieci stają się dla rodziców pośrednikami w zdobywaniu wiedzy dotyczącej funkcjonowania w środowisku lub okolicznościach znanych dziecku, a nieokreślonych dla rodziców. Przykładem może być umiejętność korzystania z zasobów nowoczesnych technologii informatycznych, ze znajomości 
języka obcego za granicą czy świadomość szkodliwości stosowania używek, o której dzieci mogą przypominać rodzicom (Knafo, Galansky 2008, s. 1146-1147).

Obszarem zmian na poziomie aksjologicznym, na który warto zwrócić uwagę, jest rozwój duchowy i religijny rodziców. Szczególną okazją do niego może być towarzyszenie dziecku w jego edukacji religijnej, zwłaszcza w przygotowaniu do pierwszej komunii świętej. Badania zmian postaw religijnych rodziców tych dzieci pokazują, że aktywne zaangażowanie dziecka w proces przygotowania do sakramentów ma wpływ na postawy religijne części rodziców, którzy włączają się w proponowane formy przygotowań (Godawa 2008, s. 131-139). Przewartościowania, jakie dokonują się w tym procesie, odzwierciedlają się w intensyfikacji zachowań religijnych, poszerzaniu wiedzy religijnej i znajomości zasad, a także uaktywnieniu sfery uczuciowej. W trakcie przygotowań dziecko staje się „nośnikiem" wartości, które odkrywa, niejednokrotnie korzystając także z pomocy rodziców. Warto przywołać wypowiedź jednej z matek, która podkreśla znaczenie pytań stawianych przez dziecko: „Nagle wywołują człowieka do tablicy i musi się zniżyć do poziomu tego dziecka, wytłumaczyć mu niektóre rzeczy. Tak było, gdy dziecko mi zadało pytanie: «Co to jest łaska uświęcająca?»" (Godawa 2008, s. 120). Pytanie dziecka i „zniżenie się" do jego poziomu zainspirowało matkę do ponownego odkrycia znaczenia pojęcia związanego z jej wiarą.

Proces różnicowania wartości polega na tworzeniu przez rodziców dwóch oddzielnych systemów wartości, z których jeden jest uznawany przez nich, a drugi jest ukierunkowany na dziecko. Rodzice dokonują tego rozróżnienia, mając świadomość, że ich system wartości nie zawsze odpowiada oczekiwaniom, jakie społeczeństwo będzie mieć w przyszłości wobec ich dzieci. Efektem tego założenia może być zminimalizowanie obiektywnego charakteru przekazywanych wartości, co wpływa na osłabienie wyrazistości norm moralnych i pomaga unikać konfliktów aksjologicznych. Z drugiej strony rodzice mogą przekazać dzieciom system wartości, który będzie spójniejszy od tego, który sami uznają, nie chcąc, by dziecko powielało ich niekonsekwentne postawy. Mogą także potraktować wychowanie dziecka jako okazję do sprecyzowania własnych wartości i uczynienia ich systemu bardziej spójnym.

Powyższe rozważania można odnieść do przebiegu procesu socjalizacji konsumenckiej w rodzinie, której kształt zależy od wartości i postaw wychowawczych rodziców. Przekazanie przez rodziców, a zwłaszcza przez ojca, spójnie zbudowanego systemu wartości ułatwia dzieciom nabywanie prawidłowych postaw konsumenckich (Dykalska-Bieck, Zawadzka, Lipowska 2017, s. 649). By temu sprostać, rodzice mogą próbować tak modyfikować swoje zachowania, by stanowiły one dla dzieci oparcie w budowaniu właściwego stosunku do wartości materialnych. Taka postawa zewnętrzna nie zawsze oznacza, że wewnętrzna hierarchia wartości rodziców faworyzuje wartości niematerialne. 
Rozważanie wzajemnego wpływu jako oddzielnej kategorii pozwala dostrzec obecne w nim zależności. Aby zaistniał wzajemny wpływ, niezbędna jest otwartość i współpraca obu stron. Dzieci muszą być otwarte na wpływ rodziców i odwrotnie. Wzajemna zgodność odnosi się do sytuacji, w której rodzice starają się z uwagą rozpoznać oraz zaspokoić potrzeby i pragnienia dzieci. Dzieci również chcą odpowiedzieć gotowością poznania oczekiwań rodziców. Gdy dzieci są gotowe do poznania oczekiwań rodziców, zmiany w wartościach dzieci i rodziców są współzależne. Współpraca dorastających dzieci z rodzicami może obejmować kształtowanie wspólnego systemu wartości. Warto podkreślić, że dzieci wrażliwych i czułych rodziców łatwiej akceptują system wartości rodzicielskich. Z drugiej strony cechą ułatwiającą akceptację wpływu dzieci na rodziców jest uległość dziecka (Knafo, Galansky 2008, s. 1149). Można więc przyjąć, że sposób wzajemnego uczenia się wartościowania zależy w dużej mierze od jakości więzi i relacji rodzinnych. Jak zauważa Leokadia Szymczyk, duży wpływ ma również poziom kultury współżycia w rodzinie, który przeciwstawia się tendencji do narzucania hierarchii wartości innym członkom rodziny (Szymczyk 2017, s. 10). Z kolei otwartość na wspólne odkrywanie znaczenia uznawanych wartości stanowi bazę do ich obopólnej akceptacji.

Szczególnym przypadkiem wpływu wartości dziecięcych na system wartości uznawany przez rodziców jest przeciwstawienie wartości uznawanych przez dzieci i rodziców. Wpływają na to napięcia międzypokoleniowe, które nasilają się szczególnie w rodzinie, która jako grupa wiekowo heterogeniczna jest narażona na konfrontację różniących się systemów aksjologiczno-normatywnych (Wrzesień 2000, s. 65). Przeciwstawienie wartości zachodzi, wówczas gdy wartości rodzicielskie i dziecięce znacznie różnią się między sobą, a różnice te wzmacnia postępowanie obu stron (Gurba 2013, s. 24). Zabieganie o zmianę zachowania dziecka, które uznaje antyspołeczne wartości, może doprowadzić do wzmocnienia znaczenia wartości uznawanych przez rodziców. W tym znaczeniu buntownicza postawa młodzieży wobec zastanych wartości może sprawić, że rodzice nabiorą jeszcze większego dystansu do wartości promowanych przez ich dzieci (Knafo, Galansky 2008, s. 1149-1150).

Istotnym czynnikiem wpływającym na mechanizm przeciwstawiania wartości jest poziom komunikacji wewnątrzrodzinnej. Usztywnienie granic systemu rodzinnego uniemożliwia otwartą komunikację, a niemożność rozmawiania o najważniejszych wartościach utrudnia ich percepcję i wymienność (Karmolińska-Jagodzik 2012, s. 201-202). Konflikty wewnątrzrodzinne mające aksjologiczne podłoże stanowią istotny problem wielu współczesnych rodzin. 


\section{PODSUMOWANIE}

Skupienie uwagi na roli dziecka w przekazie wartości w rodzinie pozwala dostrzec interesujący obszar jego oddziaływania na dorosłych członków rodziny. Pajdocentryczne spojrzenie na procesy zachodzące w rodzinie pozwala odkryć niezwykłą rolę dziecka w edukacji aksjologicznej: „W pewnym momencie bowiem to właśnie dziecko (rozumiane już jako korelat rodzica) staje się mistrzem odsłaniającym rodzicowi swój świadomościowy mikrokosmos obejmujący tę jedyną w sobie uczuciowość czy te jedyne w sobie problemy życiowe. Ów nowy mistrz może wprowadzać rodzica w szczegóły techniczne, ale może także (czasami dość gwałtownie) eksplikować ewentualne błędy rodzica dotyczące fundamentalnych rozstrzygnięć filozoficznych czy decyzji życiowych. Może także stać się surowym recenzentem dysonansu zachodzącego między rodzicielskim obrazem świata - semantycznie prezentowanym na przestrzeni wielu lat - a konkretnymi rodzicielskimi decyzjami, które de facto rozmijają się z prawdami deklarowanymi i przekazywanymi dziecku" (Kmiecikowski 2016, s. 39).

Spostrzeżenia Waldemara Kmiecikowskiego wydają się trafne. Ukazują one relację dziecka i rodzica jako inspirację do podejmowania wysiłku samowychowania. Przyjęcie przez rodzica perspektywy partnera czy nawet ucznia daje mu szansę na wewnętrzny wzrost, odnalezienie świeżości spojrzenia na świat, a niejednokrotnie jest także bodźcem do wewnętrznej przemiany moralnej. W tej perspektywie zasadny wydaje się postulat dążenia do osiągnięcia symetrii w zakresie wzajemnych oddziaływań wychowawczych między rodzicami a dziećmi.

Nie można jednak ulec iluzji wychowawczej, jaką jest przypisanie dziecku kluczowej roli w przekazie wartości w rodzinie. W skrajnym przypadku mogłoby to prowadzić do sytuacji, którą opisuje Robert Spaemann. Po tzw. rewolucji kulturowej w Niemczech po 1933 roku manipulacja ideologiczna ukierunkowana na młodzież zakładała demontaż wychowania w rodzinie oparty na uniwersalnych wartościach wynikających $\mathrm{z}$ humanizmu. Jedno $\mathrm{z}$ haseł propagujących te założenia brzmiało: „Młodzież może być prowadzona tylko przez młodzież” (Spaemann 2001, s. 490-491; za: Kożuchowski 2016, s. 22). Odrzucenie roli i znaczenia rodziców prowadziło do chaosu na płaszczyźnie wychowania i doprowadziło do destrukcji społecznej.

Rodzice wciąż pozostają osobami, od których oczekuje się kompetencji i odpowiedzialności wychowawczej. To oni wprowadzają dzieci w świat wartości, oparty na wybranej i uznawanej przez nich hierarchii. Ich rola jest nie do zastąpienia, mimo że jej realizacja nie jest łatwa. Mrzonką więc byłoby oczekiwanie na to, by asymetryczność stosunku wychowawczego w rodzinie uległa tak radyklanym zmianom, by można mówić o równowadze pomiędzy rodzicami i dziećmi czy 
o przewadze dzieci nad rodzicami w układzie wychowawczym. Taki układ nie występuje nawet w egalitarnym modelu funkcjonowania rodziny (Kawula 2007, s. 64). Niesymetryczny rozkład akcentów w wychowaniu rodzinnym nie wyklucza jednak potrzeby zauważenia i dowartościowania roli dzieci w procesie przekazu wartości, na czym korzystają wszyscy członkowie rodziny.

\section{LITERATURA}

Buczek W., 2015, Wychowanie dialogowe ku wartościom w rodzinie jako pomoc w twórczym zaangażowaniu człowieka w nauczaniu Jana Pawła II. „Rozprawy Społeczne”, t. 9 , $\mathrm{nr} 4,16-22$.

Chałas K., 2006, Wychowanie ku wartościom. Elementy teorii i praktyki, t. 1, Godność, wolność, odpowiedzialność, tolerancja. Lublin-Kielce, Wydawnictwo Jedność.

Cudak H., 2011, Od Redakcji. „Pedagogika Rodziny. Family Pedagogy”, t. 1, nr 1, 5-6.

Dudzik I., Nowak S., 2017, Rola wartości w życiu współczesnego człowieka. Na podstawie przeprowadzonych badań własnych. W: I. Dudzik, B. Czuba, K. Rejman (red.), Rola wartości etycznych we wspótczesnym świecie, cz. I, Wartości etyczne współczesnego człowieka. Jarosław, Wydawnictwo Państwowej Wyższej Szkoły Techniczno-Ekonomicznej im. ks. Bronisława Markiewicza, 9-22.

Dykalska-Bieck D., Zawadzka A.M., Lipowska M., 2017, Wychowanie w kulturze konsumpcji. Postawy wychowawcze rodziców a tendencje materialistyczne dzieci 5-6-letnich. „Polskie Forum Psychologiczne”, t. 22, nr 4, 636-655. DOI: 10.14656/ PFP20170407.

Galarowicz J., 2011, Nowy elementarz etyczny. Kraków, Wydawnictwo Petrus.

Godawa G., 2008, Przemiany w postawach religijnych rodziców uczniów przygotowujących się do pierwszej spowiedzi i Komunii Świętej. Kraków, Wydawnictwo Naukowe Papieskiej Akademii Teologicznej.

Gurba E., 2013, Nieporozumienia z dorastającymi dziećmi w rodzinie. Uwarunkowania i wspomaganie. Kraków, Wydawnictwo Uniwersytetu Jagiellońskiego.

Jezierska-Wiejak E., 2013, Rodzina jako międzypokoleniowa płaszczyzna transmisji wartości. „Wychowanie w Rodzinie”, t. 8, nr 2, 285-299.

Karmolińska-Jagodzik E., 2012, Komunikacja międzypokoleniowa - rozważania wokót różnic kulturowych. „Studia Edukacyjne”, nr 21, 191-210.

Kawula S., 2007, Rodzina jako grupa i instytucja opiekuńczo-wychowawcza. W: S. Kawula, J. Brągiel, A.W. Janke (red.), Pedagogika rodziny. Obszary, panorama problematyki. Torun, Wydawnictwo Adam Marszałek, 47-81.

Kmiecikowski W., 2016, Porozumienie między rodzicami a dziećmi jako problem i zadanie. Kilka wgladów fenomenologicznych. W: E. Karmolińska-Jagodzik (red.), 
Międzypokoleniowe relacje młodzieży z rodzicami. Wybrane konteksty edukacyjne. Leszno, Wydawnictwo Wyższej Szkoły Humanistycznej im. Króla Stanisława Leszczyńskiego, 25-46.

Knafo A., Galansky N., 2008, The Influence of Children on Their Parents' Values. „Social and Personality Psychology Compass", t. 2, nr 3, 1143-1161. DOI: 10.1111/j.17519004.2008.00097.x.

Kornas-Biela D., 2009, Pedagogika prenatalna. Nowy obszar badań naukowych. Lublin, Wydawnictwo KUL.

Kotarba A., 2011, Wczesnodziecięce przywiązanie a dorosłe relacje. Determinizm czy niezależność? „Rocznik Naukowy Kujawsko-Pomorskiej Szkoły Wyższej w Bydgoszczy. Transdyscyplinarne Studia o Kulturze (i) Edukacji”, nr 6, 89-96.

Kożuchowski J., 2016, Wychowanie jest aktem odwagi. Wizja Roberta Spaemanna. „Wychowanie w Rodzinie”, t. 13, nr 1, 19-35.

Kuczynski L., 2003, Beyond Bidirectionality. Bilateral Conceptual Frameworks for Understanding Dynamics in Parent-Child Relations. W: L. Kuczynski (red.), Handbook of Dynamics in Parent-Child Relations. Thousand Oaks, CA: SAGE Publications, 3-24. DOI: 10.4135/9781452229645.n1.

Okoń W., 2004, Wartość. W: W. Okoń, Nowy słownik pedagogiczny. Warszawa, Wydawnictwo Akademickie Żak, 449.

Ryczan K., 1997, Wychowanie ku wartościom. W: M. Piotrowski (red.), Na przełomie stuleci. Naród - Kościót - Państwo w XIX i XX wieku. Ksiegga jubileuszowa dedykowana Profesorowi Ryszardowi Benderowi. Lublin, Klub Integracji Katolickiej, 551-556. Sowiński A.J., 2013, Podmiotowy charakter stosunku wychowawczego. W: J. Krukowski, A. Wołoch (red.), Szkoła twórcza w odtwórczym świecie. Kraków, Wydawnictwo Wydziału Pedagogicznego Uniwersytetu Pedagogicznego im. Komisji Edukacji Narodowej, 362-371.

Spaemann R., 2001, Über den Mut zur Erziehung. W: R. Spaemann, Grenzen. Zur ethischen Dimension des Handelns. Stuttgart, Klett-Cotta, 490-502.

Suchocka A., 2011, Przemoc symboliczna jako element ukrytego programu kształcenia polskiej szkoly. „Zeszyty Naukowe Akademii Marynarki Wojennej”, r. LII, nr 4 (187), 293-302.

Szymczyk L., 2017, Rola rodziny w rozwijaniu systemu wartości. „Łódzkie Studia Teologiczne", t. 26, nr 1, 7-20.

Vohra N., What Can Adults Learn from Children?, opublikowano: https://www.quora. com/What-can-adults-learn-from-children [dostęp: 10.10.2018].

Wrzesień W., 2000, Relacje międzypokoleniowe a rodzina. „Roczniki Socjologii Rodziny", t. 12, 57-70.

Zarzecki L., 2012, Teoretyczne podstawy wychowania. Teoria i praktyka $w$ zarysie. Jelenia Góra, Karkonoska Państwowa Szkoła Wyższa. 


\title{
FAMILY VALUES TAKEN FROM CHILDREN
}

\begin{abstract}
The transmission of values in the family is usually aimed at the child. However, children may also influence parents' values, which results from the significance of interactions in the axiological education in the family. These interactions provide a basis for the mutual transmission of communication and enable the child to influence the hierarchy of its parents' values. This influence may be passive or active, it may involve differentiation of values or reciprocal strengthening. It may also be counter-influence. The description of these areas emphasises the significance of the parental relationship in the family and the possibility to modify it. At the same time, it highlights the right approach to the child's role in the axiological changes in the family.
\end{abstract}

Keywords: child, parents, transmission of values 